\title{
DEGUM-Preisträger
} 2015

\section{Wissenschaftspreis 2015}

$\nabla$

Dr. med. Jonas Schiffmann erhält den DEGUM-Wissenschaftspreis 2015 für die 3 Originalarbeiten:

- „Does HistoScanning ${ }^{\mathrm{TM}}$ predict positive results in prostate biopsy? A retrospective analysis of 1,188 sextants of the prostate“

- "HistoScanning has low sensitivity and specificity for seminal vesicle invasion" und

- "Comparison of prostate cancer volume measured by HistoScanning ${ }^{\mathrm{TM}}$ and final histopathological"

\section{Promotionspreis 2015}

$\nabla$

Patrick Koczera, Aachen, erhält den Promotionspreis 2015 für die Arbeit:

- „Functionalized microbubbles for facilitating translational molecular ultrasound studies and for mediating and monitoring blood-brain barrier permeation“ 